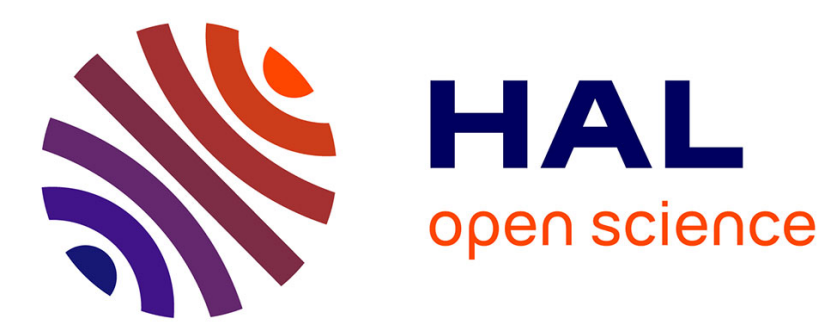

\title{
The Titicut Follies
}

Thomas Szasz

\section{To cite this version:}

Thomas Szasz. The Titicut Follies. History of Psychiatry, 2007, 18 (1), pp.123-125. 10.1177/0957154X07073814 . hal-00570885

\section{HAL Id: hal-00570885 \\ https://hal.science/hal-00570885}

Submitted on 1 Mar 2011

HAL is a multi-disciplinary open access archive for the deposit and dissemination of scientific research documents, whether they are published or not. The documents may come from teaching and research institutions in France or abroad, or from public or private research centers.
L'archive ouverte pluridisciplinaire HAL, est destinée au dépôt et à la diffusion de documents scientifiques de niveau recherche, publiés ou non, émanant des établissements d'enseignement et de recherche français ou étrangers, des laboratoires publics ou privés. 
History of Psychiatry, 18(1): 123-125 Copyright (C) 2007 SAGE Publications (London, Thousand Oaks, CA and New Delhi) www.sagepublications.com [200703] DOI: 10.1177/0957154X07073814

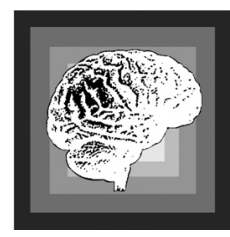

\section{News and Notes}

\section{The Titicut Follies: the forgotten story of a case of psychiatric censorship}

THOMAS SZASZ*

State University of New York

Psychiatry, being closely associated with both sex and violence, is a popular subject in the cinema. The most famous psychiatric film of all times, One Flew Over the Cuckoo's Nest (1962) - based on Kesey's novel and directed by Milos Forman - was seen by millions and is often credited with stimulating social reform. If by 'social reform' we mean advancing the cause of liberating imprisoned 'patients' from imprisoning psychiatrists, there is no evidence that it had such an effect. However, a very different film - The Titicut Follies (1967), a documentary by the noted film maker FrederickWiseman (b. 1930) - might have made a desirable impact, had many people seen it. But it was banned.

In the 1960s Wiseman received permission to film, for 29 days, inside the Bridgewater State Hospital, an institution for the criminally insane. The movie he made there - his first documentary - was shown to great acclaim at the New York Film Festival in 1967. The Massachusetts Attorney General proceeded to bar public screenings and the state's Supreme Court ruled that the movie constituted an invasion of the privacy of the Bridgewater guards and patients. Today, The Titicut Follies, if it is remembered at all, is dismissed as representing the kinds of inhumane psychiatric conditions that, thanks to drugs and deinstitutionalization, we have put behind us.

Wiseman does not interview his subjects, nor does he narrate or comment on what happens. He describes his approach to film-making as follows: '[My films are] based on un-staged, un-manipulated actions ... I think I have an obligation, to the people who have consented to be in the film, ... to cut it

\footnotetext{
* Address for correspondence: 4739 Limberlost Lane, Manlius, NY 13104, USA. Email:
} TSZASZ@aol.com 
so that it fairly represents what I felt was going on at the time in the original event.' (Wiseman, 2006). In May 1987, The Titicut Follies was the subject of a forum at the University of Massachusetts. The anonymous reviewer for the New York Times (1987) reported:

It was a rare screening of the film that, under court guidelines, can be shown only to professionals in the legal, human services, mental health and related fields. ... A documentary film about brutality at a state hospital for the mentally ill, made 20 years ago and promptly banned, has proved that its power to provoke debate has not diminished... 'Titicut Follies' shows men like Jim, kept naked in solitary confinement for 17 years. Guards who are shown taunting him about his dirty cell later complain that when they control unruly patients with tear gas, the fumes cling to their clothes. The title of the documentary comes from an annual variety show given by inmates and guards; Titicut is an Indian word describing the region south of Boston, where the hospital is located. 'Titicut Follies' ... is the only American film ever censored for reasons other than obscenity or national security ... The United States Supreme Court has twice refused to hear Mr. Wiseman's appeal. Mr. Wiseman said in an interview this week: ... 'If the First Amendment of the Constitution protects anything, it's a journalist's right to report on conditions in a prison.' ... Blaire Perry, a lawyer for Mr. Wiseman who was on the panel, said, 'In 20 years, not one patient or his family has ever objected to the showing of the film.' ... Today, the state hospital is in a modern building. By all accounts, the staff is better trained and there are more legal safeguards protecting the patients, many of whom have never been convicted of a crime. But the hospital is still surrounded by barbed wire, staffed by 220 prison guards ... There are 25 nurses and 49 psychiatrists, psychologists and social workers for 436 patients, according to Mary McGeown, a spokeswoman for the Corrections Department. Bridgewater is still overcrowded, understaffed and underfinanced, according to one panel member, Dr. Robert Fein, assistant commissioner of mental health. [emphasis added]

What is the staff better trained for? No matter how many psychiatrists, psychologists, nurses and social workers are in such a 'hospital,' they are all jailers.

On 6 April 1993 - twenty-six years after it was banned - The Titicut Follies was shown on the Public Broadcasting System and reviewed by film critic Walter Goodman (1993) in the New York Times:

Frederick Wiseman's remarkable first documentary, an unsparing visit to the Bridgewater State Hospital for the Criminally Insane, in Massachusetts, was banned by the state's Supreme Court on the grounds that it violated the privacy of inmates, several of whom were shown naked. The ban was finally overturned in 1991 ... As in all his reports, Mr. Wiseman abjures narration. The pictures tell his stories, and he has never presented more powerful pictures. The 90-minute film opens and ends with a chorus line from what was evidently an annual show called 'The Titicut Follies.' 
You'll have to guess who among these costumed performers are inmates, who are guards. The stage, where odd behavior reigns, blurs the lines of sanity and confers an hour of equality. ... One man outtalks the doctors with a fervent yet coherent plea to be sent back to an ordinary prison.... Many of the encounters have an unsettling ambiguity. A psychiatrist ... questions an inmate about his sexual proclivities: 'What are you interested in, big breasts or small breasts?' Is he working or just curious? The hardest scene to watch is of a forced feeding. The doctor smokes a cigarette as he inserts a long rubber tube into the patient's nostril and pours a liquid into a funnel; you want to call out to him to flick the lengthening ash onto the floor before it drops into the funnel. ... In the years since Mr. Wiseman made 'Titicut Follies,' most of the nation's big mental institutions have been closed or cut back by court orders. How much this ostensible victory for civil liberties has helped the mentally ill remains in dispute.

The Titicut Follies, unlike One Flew Over the Cuckoo's Nest, was a unique film: it humanized madness and depicted the psychiatric invalidation, persecution and dehumanization of so-called mad persons. For that offence, the American psychiatric establishment, assisted by the American legal establishment, banned the showing of the film. This unique violation of the First Amendment has escaped both legal and psychiatric attention.

Today, the Bridgewater State Hospital is a 'health care facility' affiliated with the University of Massachusetts Medical School. In 2003 the National Commission on Correctional Health Care lauded it as its 'Facility of Year'. An essay by Jaime Shimkus (2003), publications editor of the organization, presents a brief history of the hospital, but does not mention The Titicut Follies or the conditions described in the film.

In the days of insane asylums, the truth about psychiatry was apparent: the madhouse was a snake pit, and snake pits were limited to insane asylums. Today's 'snake pits' - dispersed throughout society - are concealed by a façade of pseudomedical 'diagnoses', 'talk therapies', 'treatment advocacy centers', 'alliances for the mentally ill' and the nominal and bureaucratic transmutation of insane asylums into 'health care facilities'.

\section{References}

Anon. (1987) Film on state hospital provocative after 20 years. New York Times, (17 May). Retrieved (17 Oct. 2006) from: http://query.nytimes.com/gst/fullpage.html?sec=health \&res=9B0DE2DD1F3DF934A25756C0A961948260.

Goodman, W. (1993) An unhealthy hospital stars in 'Titicut Follies'. New York Times, (6 Apr.). Retrieved (17 Oct. 2006) from: http://query.nytimes.com/gst/fullpage.html?res=9F0CE 3D9173DF935A35757C0A965958260.

Shimkus, J. (2003) 'Bridgewater State Hospital a model of integration'. Retrieved (17 Oct. 2006) from: http://www.ncchc.org/pubs/CC/profiles/17-4.html.

Wiseman, F. (2006). 'FrederickWiseman'. Retrieved (17 Oct. 2006) from: http://en.wikipedia. org/wiki/Frederick_Wiseman. 